\title{
The grazing pattern of Muturu cattle under range system
}

\author{
B.O. Nweze
}

Department of Animal Science and Fisheries, Ebonyi State University, Abakaliki

\begin{abstract}
Eighty Muturu cattle were grazed on rangeland, twice daily for two years to determine their grazing pattern. Twenty bulls and cows each between two to four years and forty calves between one to three months were used. The field grazing time (FGT), active grazing time (GT) and grazing travel time (GTT) were monitored. The density of the grazing area was also determined. The result showed that as the body increase, GT increased significantly, while travel distance (TD) decreased. The body weight $(B W)$ correlated positively with $G T$, with expression $B W=39.14+11.31 G$ t and $B W=7.12$ $+8.76 \mathrm{Gt}$ for morning and afternoon respectively. The grazing time (GT) increased while TD decreased with increase in forage density. However, GT and TD decreased significantly at higher density with $D+326.2+114 G t, r=4.7$ and $D=203.15+156 G T, r=3.2$ for morning and afternoon respectively. The results showed that TD was highest when the forage species are scarce (Jan and Feb in South East, Nigeria). The grazing pattern of Muturu cattle was affected by the age of animal, forage availability and temperature of the day..
\end{abstract}

Keywords: Grazing time, grazing travel time, forage density, muturu cattle

\section{Introduction}

The forage selection and consumption is controlled by both the internal and external factors. The internal factor is the state of physiological status of the herbivores. The external factor is the nature or the condition of the grazing territory and quantity and quality of the forage materials therein as well as the state of other herbivores(Wood-Gush, 1983). The consummatory behaviour of an animal usually starts with appetitive behaviour, which may eventually lead to search for food. This is a complex physiological phenomenon within the animal. (Fraser, 1980).

During grazing, a ruminant spends time grazing the forage materials of its choice to satisfy its appetite. The time spent in grazing can be regarded as grazing time (GT). But when not grazing the time is spent on some other activities such as grooming while performing these activities. Such movement can be called grazing travel (TD) and the time spent for grazing travel can be called grazing time travel (GTT). 'The GTT and GT constitute the total time spent on field by the animal while grazing. This time varies among different species of livestock (Owen, 1991). It is also influenced by many other factors. Whereas adverse weather conditions, water, scarcity, flies worry, low forage density and sickness increase grazing travel time, improvement of grazing by ways of providing good quality pasture reduces the grazing time (Fraser, 1980). Also, provision of saltlick stimulates the interest of the herbivores on forage species for a more grazing time (Fraser, 1980).

Report have shown that grazing time (GT) is positively correlated to the quantity of forage material ingested by the herbivores (Metz, 1975 and Baile, 1975; 1981). To explain the ingestion pattern or ruminant during grazing, the time spent on active grazing and the total time spent in the field should be looked into. Considering the fact that the grazing travel time (GTT) and 
the grazing time (GT) constitute the total time spent in the field grazing, and also for the fact that much energy is wasted during the grazing travel, it is important to study the conditions that influence both the grazing time (GT) and grazing travel time (GTT). This is the main thrust of this study.

\section{Materials and Methods}

Eighty Muturu cattle were involved in the study. The number of bulls and cows were twenty each, while the calves were forty in number. The ages of the bulls and cows ranged from two to four years while the calves were between one to three months of age. The cattle were grased $\mathrm{m}$ the grazing paddocks of the Muturu breeding and multiplication, Oshiri, Ebonyi State,Nigeria twice daily for two seasons (rainy and dry season). The time before and after grazing was recorded to determine the field grazing time (F(3T). The active grazing time (Gi) was determined with stopwatch. The grazing time (GTT) was calculated by: GTT $=$ FGT - GI . The grazing territory for the day was determined with the measuring tape. A quadrat of one meter square was cast for about ten times on the grazing territory. The number to forage species in each quadrat was then counted. The populatiogn of forage species (Psp) and the total number of quadrat cast $\%$. The density of forage per unit of grazing area (Dsp) was calculated as follows

$(D s p)=\frac{\mp s p \times C}{A}$ (Petruswice 1975)

Where Dsp is forage density of the grazing territory

Fsp is the frequency of forage per cast $\mathrm{C}$ is the number of quadrat cast
A is area of grazing territory

The temperature and humidity of the day were determined with the aid of maximum and minimum thermometer placed at one corner of the grazing territory. Thus, the experiment was $8 \times 2 \times 2$ factorial design. The data was analyzed by analysis of variance and treatment means separate using Duncan Multiple Range (Stecl and Torrie, 1980), with a linear model:

$Y_{i j k}=M+A_{2}+B_{j}+C_{k}+e_{i j, k 1}$

Where $\mathrm{M}$ - effect common to all the treatments

$A j=$ ellect of $i^{\text {th }}$ weight of cattle/density of furage species

$\mathrm{B}_{\mathrm{j}}=$ effect of $\mathrm{j}^{\text {th }}$ time of the day (morning and afternoon) travel distance.

$\mathrm{C}_{\mathrm{k}}=$ effect of $\mathrm{k}^{\text {th }}$ grazing time.grazing injdivdual treatment.

The grazing time and the grazing travel distance were analyzed by simple correlation analysis. The weight (W) was correlated with grazing travel distance (ID) and grazing travel time (G1) for morning and afternoon respectively.

\section{Results and Discussion}

In Table 1, the grazing time (GI) and grazing travel distance (TD) are presented. The results show that as the body weight (W) increase, the grazing travel time (GT) increased significantly whilc the graving travel distance (ID) decreased. Poth the (TD) and (GT) decreased marginally in the afternoon, which affected the focding bchaviour of the animals (Frazer, 1980). Also, it was observod that during the afternoon. the animals seek for shade or where to find rest instcad of grazing, a situation that reduces the grazing travel distance. 


\section{Grazing pattern of Muturu cattle under range}

Table 1 The average daily grazing time (GT) and grazing distance (TD) of Muturu cattle in the morning and afternoon grazing

\begin{tabular}{lllll}
\hline & \multicolumn{2}{l}{ Morning grazing } & Afternoon & \\
Temp & $28-32^{\circ} \mathrm{C}$ & & $30-35^{\circ} \mathrm{C}$ & \\
Humidity & $75-65^{\circ} \mathrm{C}$ & & $60-55^{\circ} \mathrm{C}$ & \\
Field grazing time 240.24 minutes & & 240.17 minutes \\
\hline Wt of cattle & Grazing & Grazing & Grazing & Grazing \\
(Kg) & time(minutes) & travel (minutes) & time(minutes) & travel Distance $(\mathrm{km})$ \\
\hline 60 & $30.40 \pm 4.42^{\mathrm{a}}$ & $14.00 \pm 2.51^{\mathrm{a}}$ & $28.00 \pm 4.92^{\mathrm{a}}$ & $8.15 \pm 1.55^{\mathrm{a}}$ \\
65 & $35.20 \pm 4.12^{\mathrm{a}}$ & $12.80 \pm 1.50^{\mathrm{a}}$ & $30.40 \pm 4.40^{\mathrm{a}}$ & $8.10 \pm 1.00^{\mathrm{a}}$ \\
70 & $40.40 \pm 3.92^{\mathrm{ab}}$ & $11.60 \pm 1.00^{\mathrm{b}}$ & $32.00 \pm 4.20^{\mathrm{a}}$ & $7.95 \pm 1.00^{\mathrm{b}}$ \\
80 & $46.40 \pm 4.68^{\mathrm{a}}$ & $10.30 \pm 1.00^{\mathrm{b}}$ & $36.00 \pm 3.91^{\mathrm{ab}}$ & $5.88 \pm 1.00^{\mathrm{c}}$ \\
85 & $50.40 \pm 3.42^{\mathrm{b}}$ & $9.30 \pm 1.50^{\mathrm{bc}}$ & $40.40 \pm 4.80^{\mathrm{b}}$ & $4.70 \pm 1.00^{\mathrm{c}}$ \\
110 & $53.60 \pm 3.92^{\mathrm{b}}$ & $8.34 \pm 1.00^{\mathrm{c}}$ & $47.80 \pm 3.12^{\mathrm{c}}$ & $4.5 \pm 1.00^{\mathrm{c}}$ \\
120 & $58.00 \pm 3.80^{\mathrm{c}}$ & $6.70 \pm 1.0^{\mathrm{a}}$ & $48.80 \pm 3.08^{\mathrm{c}}$ & $3.82 \pm 1.2 \mathrm{c}^{\mathrm{d}}$ \\
160 & $61.60 \pm 43.98^{\mathrm{b}}$ & $5.90 \pm 2.50^{\mathrm{d}}$ & $54.00 \pm 3.20^{\mathrm{d}}$ & $2.95 \pm 1.10^{\mathrm{d}}$ \\
Mean 93.75 & $47.00 \pm 3.89$ & $9.87 \pm 1.01$ & $39.63 \pm 3.40$ & $5.76 \pm 1.00$ \\
\hline \hline
\end{tabular}

a,b,c,d in the same column with different superscript are significant different $(\mathrm{P}<0.05)$

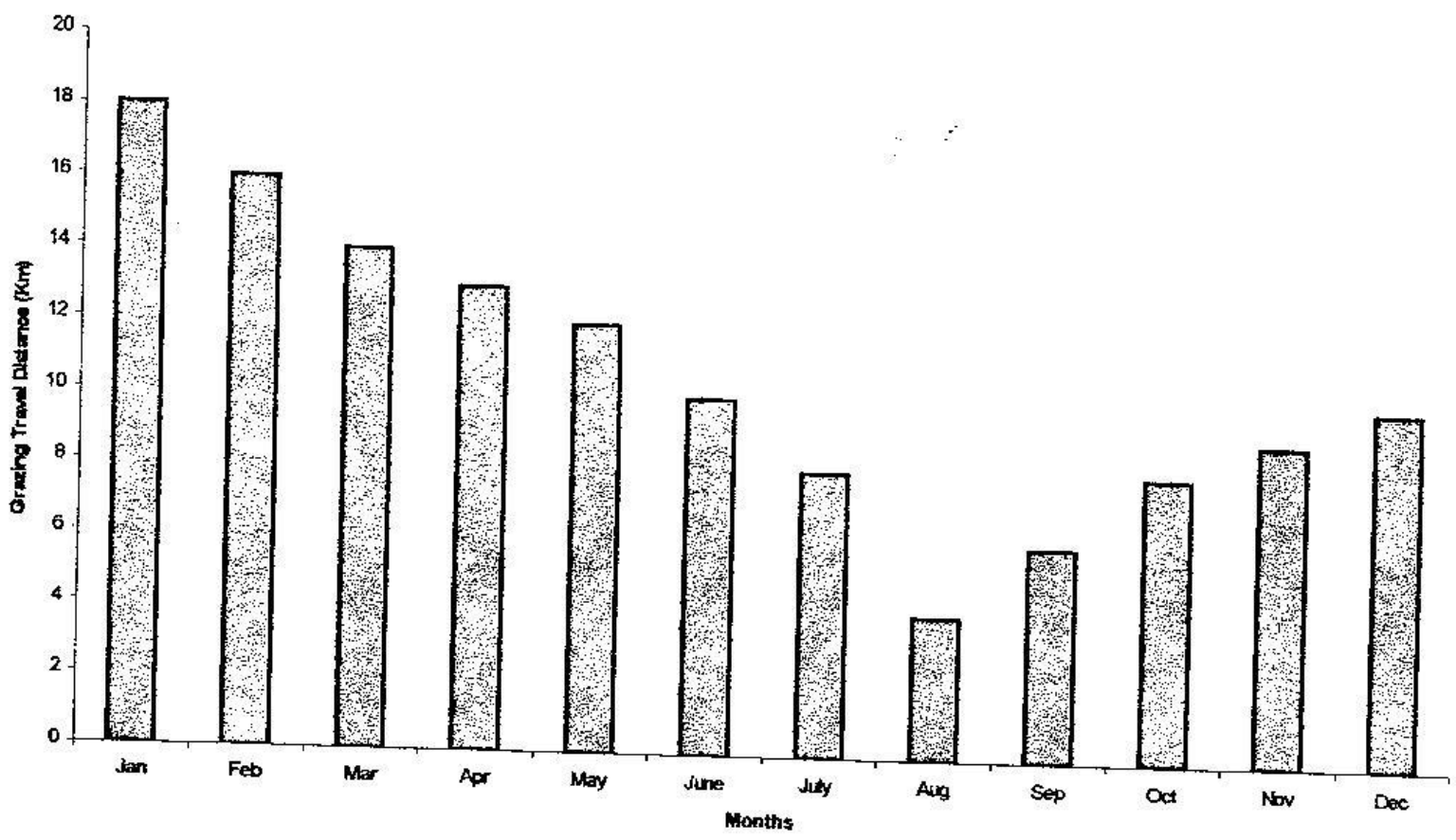

Figure 1. The Daily Grazing Distance (Km) of Muturu Cattle from January to December

In figure 1, The grazing travel distance (kilometer) of Muturu cattle from January to December is shown. From January to August, the travel distance decreased while from August to December, it increased. The highest TD was obtained in January when the cattle had TD of about $18 \mathrm{~km}$. Also, from December to May, the TD values were high. This high value of TD could be due to scarcity of forage materials, which resulted to the cattle covering much distance in search of feed to satisfy them. Rain (1972) reported that adult cattle required about 
2300 to $2700 \mathrm{~kg}$ dry matter forage per year. This means that an adult cattle requires about $6.30-$ $7.40 \mathrm{~kg}$ DM of forage materials daily, which may not be readily available during the dry season period in some pasture area. The animals have to cover much TD to look for feed to maintain themselves. However, they spent energy in doing so. Ademosun (1988), reported that trekking up to 10 kilometer lead to weight losses. Deleeuw and Brickman (1971), reported that it is common to find $15 \%$ body weight losses for cattle during the dry season period. This high TD is one of the major problems confronting dry season feeding for cattle.

The lowest TD of about $4 \mathrm{~km}$ was obtained in August. Also, between July to October, the ID was low probably due to availability of forage materials evident during the rainy season. Furthermore, the graving paths could be bushy, and water logged thus creating difficulty in the movement of cattle and their herdsmen.

The body weight is positively correlated with (GT) with expression: body weight $(B W)=$ $39.12+11.31 \mathrm{GT}$ and $\mathrm{BW}=7.12+8.26 \mathrm{GT}$ for morning and afternoon respectively. The coefficicnt of regression (r) for morning and afternoon were $r=0.91$ and $r=0.61$ respectively. This could be explained from relationship between the ingestion time or the grazing time (GT) and the body weight which have been shown in the expression as; Intake $=\mathrm{W}^{\mathrm{b}}$, where $\mathrm{W}$ is the body weight and $\mathrm{b}$ is constant (Leonard et al., 1979). Table 2 The average time (GT) and grazing distance (TD) of Muturu cattle at different forage
densities.

\begin{tabular}{|c|c|c|c|c|c|}
\hline \multicolumn{4}{|c|}{ Morning grazing } & \multicolumn{2}{|l|}{ Afternoon } \\
\hline $\begin{array}{l}\text { Temp } \\
\text { Humidity } \\
\text { Field grazi }\end{array}$ & ing ti & $\begin{array}{c}28-32^{\circ} \mathrm{C} \\
75-65^{\circ} \mathrm{C} \\
\text { ime } 240.24 \text { minutes }\end{array}$ & & $\begin{array}{l}30-35^{\circ} \mathrm{C} \\
60-55^{\circ} \mathrm{C} \\
240.17 \text { minutes }\end{array}$ & \\
\hline $\begin{array}{l}\text { Density } \\
\text { Plant/of }\end{array}$ & * & $\begin{array}{l}\text { Grazing } \\
\text { time(minutes) }\end{array}$ & $\begin{array}{l}\text { Grazing } \\
\text { iravel (minutes) }\end{array}$ & $\begin{array}{l}\text { Grazing } \\
\text { time(minutes) }\end{array}$ & $\begin{array}{l}\text { Grazing } \\
\text { Iravel Distance }(\mathrm{km})\end{array}$ \\
\hline $\begin{array}{l}390 \\
440 \\
520 \\
1490 \\
1590 \\
\text { Mean } 886\end{array}$ & $\therefore$ & $\begin{array}{l}16.16 \pm 1.10^{\circ} \\
33.04 \pm 3.00^{\mathrm{c}} \\
41.08 \pm 3.10^{\mathrm{c}} \\
50.14 \pm 3.12^{\mathrm{d}} \\
60.33 \pm 3.00^{\mathrm{c}} \\
40.28 \pm 7.52 \\
\end{array}$ & $\begin{array}{l}14.80 \pm 1.10^{\mathrm{a}} \\
12.80 \pm 1.20^{\mathrm{b}} \\
11.10 \pm 1.11^{\mathrm{c}} \\
9.10 \pm 1.20^{\mathrm{d}} \\
6.00 \pm 1.00^{\mathrm{c}} \\
10.76 \pm 1.5\end{array}$ & $\begin{array}{l}16.00 \pm 43.10^{\mathrm{a}} \\
25.00 \pm 2.99^{\mathrm{b}} \\
35.28 \pm 3.00^{\mathrm{d}} \\
42.01 \pm 3.20^{\mathrm{d}} \\
50.08 \pm 3.21^{\mathrm{c}} \\
33.67 \pm 6.04\end{array}$ & $\begin{array}{l}9.20 \pm 1.00^{\mathrm{a}} \\
8.10 \pm 1.00^{\mathrm{a}} \\
6.820 \pm 1.20^{\mathrm{b}} \\
4.32 \pm 1.00^{\mathrm{c}} \\
3.10 \pm 1.20^{\mathrm{d}} \\
6.31 \pm 1.14\end{array}$ \\
\hline
\end{tabular}

a,b,c,d in the same column with ditferent superscript are significant diflerent (P- 0.05$)$

Table 2 represents the grazing travel distance (ID) and grazing time (GT) at various densities. The result show that GT increased while (GT) decreased with increased forage density. The animals spent time feeding on areas where they found the desired forage materials whereas they made more travel distance where these feeding materials are scarce. This ubservation is in agreement with Norman and Philip, 1970. the forage density was positivcly correlated with the grazing timc, with the expression,. Density (D) $=326.20+114 \mathrm{GT}$ and $\mathrm{D}=203.15+156 \mathrm{GT}$ for morning and afternoon respectively and the correlation $(r)=4.2$ and $r=320$ respectively. The reason was that where the density of forages are high there is a tendency to find more forages

desired by the ruminants and so the unimal will spend more time in feeding them. Whereas in areas where there is low forage density, the animals have to cover more TD. This observation tend to agree with the reports by Delecurw (1985) in which he stated that movements of cantle Southward during dry season from the Northern parts was due to the decline in carrying capacity of forage species 


\section{Graxing pattern of Muturu cattle uider range}

from 5- heads of cattle $1 \mathrm{~km}$ to 10 heads. Ademosun (1985) also supported the above observation by stating that during dry season period the Fulani herdsmen trek up to 10 kilometer in search of water. From the above analysis, TD can be used to estimate the quantity of forage materials in the graving area.

\section{Conclusion}

The result revealed that the grazing travel distance is influenced by the body weight of the animals, forage density and the weather condition of the day. Also the grazing travel distance are high where forage materials scare within the year. It could therefore be recommended that ahternative grazing arrangement such as rotational grazing should always be made available to prevent the energy wasted on grazing travel when the forage species are scarce.

\section{References}

Baile,C.A., 1975, Control of feed-intake and regulation of energy balance in ruminants physiology. Rev. 54:161 - 214 .

Baile,C.A., 1981. Nature of hunger and satiety control system in ruminant. $J$ Diary Sci. $64: 1140-1152$.
Fraser,A.F., 1980. Cattle feeding behaviour, Ingestion in domestic animals, $2^{\text {nd }}$ Edition. Brunswith Canada. 161 - 162p.

Metz,J.H.M., 1975. Cattle feeding behaviour, In time pattern of feeding ruminant in domestic cattle. $58-65 p$.

Norman, M.H.I.T., and Philip, E.C. 1970. Wet season grazing of sville stio pasture of kathrina region. J. Aust. Agric. Sci. 30:46 49.

Owen, J.B., 1991. Inconcept of secondary productivity of terrestrial ecosystem: Principal and Methods" (ed). K. Petrusewicz. Oxford Pub. 17-49p.

Lenoard, A.M., John,K.C., Harold, F>h. Richard,G.W., 1979. Ingestion pattern of cattle, In animal nutrition. Seventh edition MacGraw Ltd Pub. New Delhi. 9-21p.

Wood-Gush, D.G.M., 1983. Feeding behaviours, In element Ethnology, University Press, Edinburgh U.K. 56 73p.

(Received 19 March 2001; Accepted 24 April 2002) 